UDC 36

\title{
IMPLEMENTATION OF POVERTY ALLEVIATION POLICY THROUGH INTEGRATED SERVICES FOR POOR CITIZENS IN KEBUMEN REGENCY
}

\author{
Hidayat Nur*, Domai Tjahjanulin, Haryono Bambang Santoso \\ Master's Program of Public Administration, Faculty of Administrative Science, \\ University of Brawijaya, Indonesia \\ *E-mail: hidayatneuer@gmail.com
}

\begin{abstract}
The implementation of poverty alleviation policy through integrated services as mandated by Regional Regulation Number 20 Year 2012 on acceleration of poverty alleviation aims to reduce poverty rate in Kebumen Regency by using social assistance intervention strategy through integrated service mechanism on Integrated Service Unit of Poverty Alleviation Acceleration (UPTP2K). The regency, which is located on the southern coast of Java, is ranked as the second poorest region in Central Java. This research used descriptive qualitative approach. The focus of this research was based on Grindle's theory about successful implementation of public policy that was influenced by content and context of the policy. By using interactive data analysis proposed by Miles, Huberman, and Saldana, it was known that the implementation of poverty alleviation policy through integrated service in Kebumen Regency was not running optimally. Due to the existence of egosectoral interests of agencies involved in services, the program's maker had not been able to maximize its role; program implementers had difficulties in providing information about social assistance; there were low amount of resources; and there was a low level of responsibilities held by the implementers.
\end{abstract}

\section{KEY WORDS}

Policy, implementation, integrated service, poverty, alleviation.

Poverty is a classic problem that exists almost everywhere in the world. In Indonesia, poverty is characterized by high poverty rates. By 2015, poor citizens in Indonesia amounted to 28.5 million people or with a percentage of $11.22 \%$ from a total of 254 million of Indonesians.

In the fourth paragraph of the 1945 Constitution, it is mentioned that Indonesia is a welfare state because it aims to promote the welfare of the people. In other words, the government has a strong commitment to try to reduce the number of poor citizens or alleviate the poverty. This is evident in the policies made by the Indonesian government. In 2000, the commitment was realized by the issuance of Law Number 25 Year 2000 on National Development Program (Propenas) which established poverty alleviation as one of several priorities. Furthermore, the government made the Regulation of the President of the Republic of Indonesia Number 15 Year 2010 on the Acceleration of Poverty Alleviation.

In 2014, in the era of President Joko Widodo, poverty alleviation was included in one of the Nine Priority Development Agendas (Nawacita) by improving the quality of life of Indonesians through improving the quality of education and training with a program which was called as "Indonesia Pintar"; as well as improving the welfare of the people with programs which were called as "Indonesia Kerja" and "Sejahtera Indonesia." The agenda referred to the Declaration of Sustainable Development Goals (SDGS) in September 2015 which required commitments from 193 countries in the world. The poverty alleviation agenda was then embodied in social, economic, health and educational sector such as the National Health Insurance $(J K N)$, Prosperous Rice (Rastra), Joint Business Group (KUBE) including E-Waroeng, Family Hope Program $(P K H)$, Improvement of Uninhabitable Homes $(R T L H)$ community effort credit (KUR), electricity for poor citizens and many other programs.

Nevertheless, the poverty alleviation agenda will not work if it is not implemented properly. No matter how well the preparation and planning of policy implementation, if it is not 
formulated properly, then the purpose of the policy also will not be realized (Widodo, 2008: 85).

In Kebumen Regency, Central Java Province, poverty alleviation policy is implemented through the establishment of Integrated Service Unit of Poverty Alleviation Acceleration (UPTP2K) which refers to Regional Regulation No. 20 Year 2012 on Acceleration of Poverty Alleviation. The objective is to accelerate access to integrated one-stop assistance services for social, economic, educational and health assistance. Previously, the assistance was separated, but now, it is integrated with the main objective of significantly reducing the poverty rate. It is because Kebumen Regency is the region with the second poorest population in Central Java. By 2015, the number of poor citizens of Kebumen was 241 thousand of inhabitants or $20.44 \%$.

In fact, until 2016, the decline of the number of poor citizens was still very slow, namely 241 thousand of inhabitants (20.4\%) in 2015 to 226 inhabitants or $19.86 \%$ in 2016 from the total population of Kebumen Regency as much as 1.2 million of inhabitants. The slow poverty alleviation is caused by inadequate targeted aid programs, unsuitable amount of assistance received by the poor citizens, poorly provided services such as inadequate human resources, poor service quality and lack of proper administration. (Handayani, 2017). The phenomena occured in the field include: there were assistance activities that did not work properly, there was a lack of operational funds, and there was a low quality of service implementers who had a minimal update about service information.

Considering the matters above, it is necessary to conduct a research on how to actually implement poverty alleviation policy through integrated service for poor citizens in Kebumen Regency (Study of Regional Regulation No. 20 Year 2012 on Acceleration of Poverty Alleviation).

\section{LITERATURE REVIEW}

Public Policy Implementation Theory. Public policy aims to find solutions to existing problems with various processes and considerations. In assessing the implementation of public policy, it is not separated from the theory of implementation itself. Van Meter and Van Horn stated that implementation of policies is an act committed by the government and private sector, both individually and in groups with a view to achieve the objectives as formulated in the policy (Abdul Wahab, 2016: 135). While Nugroho (2017: 728) argued that in principle, the implementation of public policy was a way for a policy to achieve its goals. To implement public policy, there were two choices of existing steps, which were directly implemented in the form of programs or through the formulation of a derivative policy of public policy.

The policy that was implemented was Regional Regulation No. 20 Year 2012 on the Acceleration of Poverty Alleviation which regulated four strategies used in poverty alleviation. However, this research only used two strategies, namely: (1) Strategy to reduce the burden of the poor with aid interventions, (2) Strategy to conduct a synergy between government agencies and private sector that had poverty alleviation programs.

Grindle Policy Implementation (1980). According to Grindle (1980) in Agustino (2014: 154 ), the successful implementation of public policy was determined by the level of policy implementation itself that consisted of two things: content of policy and context of policy (implementation context). The contents of the policy consisted of (1) Interests affected by the program; (2) Types of benefits resulting from the program; (3) The degree of desired change through the program; (4) Position of program maker; (5) Program implementers, (6) Resources deployed in the implementation of the program. The integrated service program environment for the poor consisted of: (1) The power, interests, and strategies of actors involved in program implementation; (2) Characteristics of ruling institutions and government.

Grindle in Winarno (2016: 135) also argued that the task of implementation was to establish a link that facilitated the policy objectives that could be realized as the impact of a government activity. 
Integrated Service for Poor Citizens. Presidential Regulation No. 97 Year 2014 on the implementation of one-stop integrated services explained that one-stop integrated service or PTSP was an integrated service within a single process that began from the request stage until the completion of the product through one door. In Kebumen Regency, a special PTSP for the poor was formed under the name of Integrated Services Unit for Accelerating Poverty Alleviation (UPTP2K). This unit was integrated into the social, education, health and sections of updating poverty data that were previously separated.

\section{METHODS OF RESEARCH}

This research used qualitative approach. The source of data for this research came from informants, documents, and events. The research informants came from the Head of Social Affairs, Head of Social and Culture Affairs of BP3AD, Head of Adiwarno Village, and Villagers of Adiwarno Village. On the other hand, the documents used in this research was Regional Regulation Number 20 Year 2012. The event was an integrated service process that run on Integrated Services Unit for Accelerating Poverty Alleviation (UPTP2K).

The data validity was tested by using credibility, transferability, dependability and confirmability test. The data was analyzed by using interactive models proposed by Miles, Huberman and Saldana (2014) through data condensation, data display and conclusion drawing.

\section{RESULTS AND DISCUSSION}

Based on the focus of the research that has been described before, it can be described that the variables to measure the success of implementation with Grindle model (1980) consisted of the content of integrated service programs for the poor that covered: (1) Interests affected by the program; (2) Types of benefits resulting from the program; (3) The degree of desired change through the program; (4) Position of program maker; (5) Program implementers, (6) Resources deployed in the implementation of the program. The integrated service program environment for the poor consisted of: (1) The power, interests, and strategies of actors involved in program implementation; (2) Characteristics of ruling institutions and government.; (3) The level of compliance and responsiveness of program implementers.

Interests affected by the program. Implementing strategies to reduce the burden of the poor and making synergies between agencies involved many interests. Therefore, there was an egosectoral or an interest of each agency that provided assistance related to poverty alleviation. There were agencies that were reluctant to give social assistance programs to the poor citizens. For example, Residence and Living Environment Agency was reluctant to give social assistance in the form of Uninhabitable Homes (RTLH) program because the data was already by name by adress and could not serve the poor citizens who needed sudden help. On the other hand, health assistance program by Health Agency and educational assistance programs in the form of scholarship by Educational Agency were still running.

According to Grindle (1980), interests affected by the program related to the various interests that affected a policy implementation. In the sense that a policy involved many interests and the extent to which those interests had an effect on its implementation. Denhardt and Denhardt in Sabarudin (2015: 21) explained that the public interest must remain prioritized because the actual public interest owner was the community. Therefore, public administrators should focus their attention on the responsibility of serving and empowering citizenss through the management of public organizations and the implementation of public policy.

Types of benefits resulting from the program. First, it provided benefits in terms of services to the poor citizens. Second, benefits in terms of assistance received in the form of social economic assistance, education and health, although there were people who had not received the assistance in the field. Third, benefits of updating poverty data obtained from people who had not registered in poverty data, both in BDT 2015 and TKP2Kdes. These 
benefits were enough to help easing the burden of the poor citizens and accelerated access to it because it was comrised in one integrated service.

According to Grindle (1980), these three benefits should be present in the content policy. Various types of benefits from an integrated service program in poverty alleviation efforts in Kebumen Regency showed that there were positive impyacts resulting from the implementation of the policy to be implemented. Specifically, these benefits can be felt by the community (although not all parts of community) and it gave an easy access in the implementation of poverty alleviation policies through integrated services.

The degree of desired change through the program. The expected change from the content of the integrated service program was to accelerate the access of the poor to get help in order to reduce the burden of expenditure. The point was the decrease of poverty rate according to the policy target. The acceleration of access to this service was felt by the community because the poor now have "Rumah Harapan" in the sense that there was a media to complain and to ask for a help, which was previously considered as difficult and complicated. The targets for poverty alleviation also declined in each year, although not significant. In truth, social assistance intervention was expected to accelerate the implementation process of poverty alleviation in Kebumen Regency. In other words, the change in the accelerated access of aid services to the poor corresponded with what was expected, even though the annual poverty rate declined in insignificant manner. In 2015 , there were 241 thousand of inhabitants $(19.8 \%)$ of the poor and in 2016 , it fell to 226 thousand of inhabitants $(20.4 \%)$ out of a total of 1.2 million of inhabitants.

The position of the program maker. Head of Kebumen Regency had a role as the initiator of the establishment of this institution through the Regent Regulation No.47 Year 2015 on the establishment of UPTP2K. The Regent had the authority to continue to maintain the function of UPTP2K as an integrated service institution with various poverty programs that existed in government agencies. But with the change of the Regent in 2016 and the change of the regional organizational structure, the central role of the Regent in UPTP2K was faded because new leader chose to put forward other poverty programs, such as CSR programs and infrastructure development.

It was in accordance with the opinion of Grindle (1980): the position of the program/policy maker played an important role in the implementation of the policy. It was corroborated byDavid Easton as quoted byAgustino (2014: 8) that the policy was closely related to the authority in the political system of the supreme head, executive, legislative. Therefore, the position of the program maker for integrated service programs in this case was quite difficult because the program maker was diverted with other programs.

Program implementers. The implementers of the program, namely the leader and staffs of UPTP2K still had difficulty in implementing integrated services for the poor. It was because of the lack of information related to changes that occured in the field, related to what assistance that could be provided through integrated services because there was no certainty of cooperation provided by relevant agencies. In fact, the provided information was very important because it concerned the basic needs of the poor.

The existence of the element of implementers of an integrated service program supported the theory of Grindle (1980) which stated that in running a policy or program, it must be supported by the competent and capable policy implementers for the success of a policy.

Resources deployed in the implementation of the program. Resources deployed to implement the program made the implementation of the program became difficult. These resources consisted of an insufficient number of human resources or integrated service providers (only 8 people), minimum operational costs (budget), no appreciation of the performance of the program implementers (incentives), and the absence of operational vehicle field (facilities).

In truth, according to Grindle (1980), all these resources were required as a support in the successful implementation of the program. Therefore, in order to achieve the objectives of the implemented program, it required the completeness of resources, including human resources, adequate budget, supporting facilities and incentives for program implementers. 
Therefore, according to Nugroho, in principle, implementation was a way for a policy to achieve its goals. (Nugroho, 2017: 728).

The power, interests, and strategies of actors involved in program implementation. Environmental factors such as power, interests and strategies of actors involved in the implementation could support and facilitate the implementation of the program. In terms of power, UPTP2K had a full authority or to determine who was eligible for assistance. On the other hand, external interests such as Ministry of Social Affairs and TNP2K involved in implementation strongly supported the policy of poverty alleviation. The strategy of UPTP2K as the leading sector of integrated service for poor citizens in Kebumen Regency consisted of: conducting a coordination with other aid agencies, accelerating to receive updating of poverty data at village level and being active in seeing the potential of assistance from central, provincial or private government to handle the poverty in Kebumen Regency.

Grindle (1980) stated that a policy needed to take into account the power, interests and strategies used by the actors involved in the the policy to smooth the course of a policy implementation. Edward III also suggested that the implementation indicators that wererelated to power or authority should generally be formal, so that the order can be implemented in public. (Agustino, 2014: 152).

Characteristics of ruling institutions and government. The Social Service Agency Institution that was structurally above the position of UPTP2K was appropriately placed in leading UPTP2K as the institution that focused on providing services for the poor citizens. The integration of various poverty alleviation programs in Social Service Agency and the support by the central and regional government priorities in poverty alleviation at least strengthened the role of UPTP2K in providing services in the fields of social, economy, education and health.

Related to it, Grindle (1980) explained that context implementation factor was very influential on policy implementation, especially variable characteristics of institutions that implemented policies and government in power. Van Meter and Van Horn also supported the statement by saying that there was one variable that determined the success of policy implementation: the characteristics of implementing agents that could be seen from the nature or the characteristics of the agency/instantion that implemented the policy.

Level of compliance and responsiveness of program implementers. The level of compliance and responsiveness of the service program implementers had not been maximized because there were complaints from the community who received the service in UPTP2K. Weak response in serving was caused by the lack of human resources and lack of information provided by superiors related to assistance programs that could be given to the community.

Parasurahman cited Dwiyanto (2008: 145) argued that responsiveness was one dimension to measure the quality of service to the community. Van Meter and Van Horn explained the importance of the role of the disposition of the implementor that consisted of the response of the implementor, the understanding of the policy and the preference of value owned by the implementors (Nugroho, 2017: 99).

\section{CONCLUSION}

The implementation of poverty alleviation policy through integrated services for poor citizens in Kebumen Regency had not been running optimally. In terms of the content of the integrated service program, there were five obstacles that caused the policy did not run optimally, namely: First, agencies which worked together in the integrated service of UPTP2K had egosectoral interest in implementing poverty alleviation programs; Second, the position of the program maker had not been able to maximize its role; Third, the program implementer still could not implement the program well because of the lack of information related to the changes that existed in the field that was related to the assistance that could be given through the integrated service; Fourth, the resources deployed to implement the program were still minimal such as the number of human resources, the lack of operational costs, no appreciation of the performance of the program implementers and the absence of 
operational vehicle field; Fifth, the level of compliance and responsiveness of program implementers that were still weak that made the integrated service became stalled which resulted in the emergence of complaints from the community.

\section{REFERENCES}

1. Agustino, L. (2014). Dasar-dasar Kebijakan Publik. Bandung: Alfabeta.

2. Dwiyanto, A. (2008). Mewujudkan Good Governance Melalui Pelayanan Publik. Yogyakarta: UGM Press.

3. Handayani, S. (2017). Perkembangan Kemiskinan Kabupaten Kebumen. Paper presented in "Rapat Penanggulangan Kemiskinan Kabupaten Kebumen", Kebumen, Indonesia, April 25 $5^{\text {th }}, 2017$.

4. Nugroho, R. (2017). Public Policy (6 ${ }^{\text {th }}$ Ed). Jakarta: PT Elex Media Komputindo.

5. Peraturan Daerah Nomor 20 Tahun 2012 tentang Percepatan Penanggulangan Kemiskinan

6. Sabarudin, A. (2015). Manajemen Kolaborasi dalam Pelayanan Publik, Teori, Konsep dan Aplikasi. Yogyakarta: Graha IImu.

7. Widodo, J. (2008). Analisis Kebijakan Publik. Malang: Banyumedia Publishing.

8. Winarno, B. (2016). Kebijakan Publik Era Globalisasi. Yogyakarta: CAPS (Center of Academic Publishing Service). 